\title{
Proposal to Conserve the Specific Epithet tarda over the Specific Epithet anguillimortiferum in the Name of the Organism Presently Known as Edwardsiella tarda
}

\author{
Request for an Opinion
}

\author{
J. J. FARMER III, DON J. BRENNER, and WILLIAM A. CLARK ${ }^{1}$ \\ Enteric Section, Bacteriology Division, Center for Disease Control, Atlanta, Georgia 30333
}

We propose that the specific epithet tarda be conserved over the specific epithet anguillimortiferum in the scientific name Edwardsiella tarda Ewing et al. 1965. Although the name Paracolobactrum anguillimortiferum was applied to what may be the same organism and was validly published by Hoshina in 1962 , the name remained obscure until it was rediscovered by Sakazaki and Tamura in 1975. Meanwhile, the name Edwardsiella tarda has gained worldwide acceptance. For stability in nomenclature and to avoid confusion in the literature, the specific epithet tarda should be retained.

Between 1962 and 1965 three research groups working independently described a new group of bacteria in the family Enterobacteriaceae. Sakazaki and Murata called these bacteria the "Asakusa Group" (8), and King and Adler called them the "Bartholomew Group" (7). In 1965 Ewing and co-workers described 37 isolates of this group and placed them in a new genus, Edwardsiella, with a single species, $E d$ wardsiella tarda (3).

In 1975 Sakazaki and Tamura (9) pointed out that in 1962 Hoshina (4) described a new bacterium that he called Paracolobactrum anguillimortiferum (no type strain was designated by Hoshina, and apparently no cultures of the strains on which Hoshina based his description have survived). Sakazaki and Tamura correctly stated that, if Paracolobactrum anguillimortiferum and Edwardsiella tarda are synonyms, then the specific epithet anguillimortiferum would have priority, since it was validly published 3 years before the specific epithet tarda. Sakazaki and Tamura "proposed Edwardsiella anguillimortifera (Hoshina comb. nov. to replace the illegitimate combination Edwardsiella tarda (9)."

We propose that the specific epithet tarda be conserved over the specific epithet anguillimortiferum in Edwardsiella on the basis of the following considerations. Since the name $E d$ wardsiella tarda was published in the International Bulletin of Bacteriological Nomenclature and Taxonomy 10 years ago (3), it has gained worldwide acceptance by bacteriologists. No other name for this organism appears in Bergey's Manual of Determinative Bacteriology

\footnotetext{
' Visiting Scientist with the Bacteriology Division.
}

(2). The name Paracolobactrum anguillimortiferum was published in the Japanese Bulletin of Scientific Fisheries (4), a journal unlikely to reach working bacteriologists. As a consequence, the latter name has seldom been used for this organism. $P$. anguillimortiferum does not appear in the Index Bergeyana (1), published 4 years after the name appeared in print.

We suggest that conservation of the specific epithet tarda can be justified by citing Principle 1 of the International Code of Nomenclature of Bacteria and Viruses (5): "The essential points in nomenclature are (1) to aim at fixity of names; (2) to avoid or to reject the use of names which may cause error or ambiguity or throw science into confusion." The stability of nomenclature would be served best by conserving the specific epithet tarda over the specific epithet anguillimortiferum. Acceptance of the latter epithet would violate the intent of Principle 1 as quoted above.

In Opinion 18 (6), the Judicial Commission of the International Committee on Bacteriological Nomenclature conserved typhi over typhosa as the specific epithet for the typhoid bacillus despite the fact that typhosa had priority over typhi. In issuing its opinion, the Judicial Commission cited Principle 1 of the International Code of Nomenclature of Bacteria and Viruses. Their decision was based upon the more common usage of the epithet typhi as compared with that of the epithet typhosa. In the opinion, it was stated "that acceptance of typhi rather than typhosa was desirable in order to minimize confusion in the literature (6)."

Therefore, in the interest of stability in nomenclature and to avoid confusion in the litera- 
ture, we request that the Judicial Commission of the International Committee on Systematic Bacteriology issue an opinion conserving the specific epithet tarda over anguillimortiferum in the scientific name Edwardsiella tarda (Ewing and McWhorter). The type strain would remain ATCC 15947 (= CDC 1483-59).

\section{REPRINT REQUESTS}

Address reprint requests to: Center for Disease Control, Attn: J. J. Farmer III, Enteric Section Building 1, Room B-341, 1600 Clifton Road, Atlanta, Ga. 30333.

\section{LITERATURE CITED}

1. Buchanan, R. E., J. G. Holt, and E. F. Lessel, Jr. (ed.). 1966. Index Bergeyana. The Williams and Wilkins Co., Baltimore.

2. Buchanan, R. E., and N. E. Gibbons (ed.). 1974. Bergey's manual of determinative bacteriology, 8th ed. The Williams and Wilkins Co., Baltimore.

3. Ewing, W. H., A. C. McWhorter, M. R. Escobar, and A. H. Lubin. 1965. Edwardsiella, a new genus of
Enterobacteriaceae based on a new species, E. tarda. Int. Bull. Bacteriol. Nomencl. Taxon. 15:33-38.

4. Hoshina, T. 1962 . On a new bacterium, Paracolobactrum anguillimortiferum n. sp. Bull. Jpn. Soc. Sci. Fish. 28:162-164.

5. International Committee on Bacteriological Nomenclature (ed.). 1958. International code of nomenclature of bacteria and viruses. Iowa State Univ. Press, Ames.

6. International Committee on Nomenclature of Bacteria. Judicial Commission. 1963. Opinion 18: conservation of typhi in the binary combination Salmonella typhi. Int. Bull. Bacteriol. Nomencl. Taxon. 13:31-32.

7. King, B. M., and D. L. Adler. 1964. A previously undescribed group of Enterobacteriaceae. Am. J. Clin. Pathol. 41:230-232.

8. Sakazaki, R., and Y. Murata. 1962. The new group of the Enterobacteriaceae, the Asakusa group. Jpn. J. Bacteriol. (In Japanese) 17:617-618.

9. Sakazaki, R., and K. Tamura. 1975. Priority of the specific epithet anguillimortiferum over the specific epithet tarda in the name of the organism presently known as Edwardsiella tarda. Int. J. Syst. Bacteriol. 25:219-220. 